
ISSN : 2615-1995, E-ISSN : 2615-0654

J. Madani., Vol. 3, No. 2, September 2020 (164 - 173)

(C)2018 Lembaga Kajian Demokrasi

dan Pemberdayaan Masyarakat (LKD-PM)

DOI : https://doi.org/10.33753/madani.v3i2.108

\title{
Pengaruh Motivasi dan Stres Kerja Terhadap Kinerja Karyawan CV Muslim Galeri Indonesia
}

\author{
Nina Shabrina \\ Fakultas Ekonomi, Universitas Pamulang \\ dosen015617@unpam.ac.id \\ Darmadi \\ Fakultas Ekonomi, Universitas Pamulang \\ dosen02445@unpam.ac.id \\ Ratna Sari \\ Fakultas Ekonomi, Universitas Pamulang \\ dosen02442@unpam.ac.id
}

\begin{abstract}
Abstrak
Penelitian ini bertujuan untuk mengetahui pengaruh lingkungan kerja dan disiplin kerja baik secara parsial maupun secara simultan terhadap kinerja karyawan pada PT. Caturkarda Depo Bangunan Serpong Tangerang. Metode yang dipakai dalam penelitian ini menggunakan Asosiatif dengan pendekatan kuantitatif adapun sampel yang digunakan dalam penelitian ini sebanyak 85 responden. Tehnik pengumpulan data dengan cara kuesioner, tehnik analisis data dengan uji validitas, reliabilitas, uji asumsi klasik, analisis regresi berganda, uji hipotesis uji $t_{\text {hitung }}$ uji F, dan koefisien determinasi. Hasil penelitian menunjukan bahwa lingkungan kerja berpengaruh positif dan signifikan terhadap kinerja karyawan hal ini dapat dibuktikan oleh nilai regresi $0,091 X_{1}$. Nilai $t_{\text {hitung }} 3,086>t_{\text {tabel }} 1_{989}$ dengan signifikan 0,003 $<0,05$. Serta nilai koefisien determinasi sebesar 28,5\%. Disiplin kerja berpengaruh positif dan signifikan terhadap kinerja karyawan hal ini dapat dibuktikan oleh nilai regresi $0,173 X_{2}$. Nilai $t_{\text {hitung }} 4,612>t_{\text {tabel }}$ 1,989 dengan signifikan 0,000 $<0,05$. Serta nilai koefisien determinasi 36,6\%. Secara simultan lingkungan kerja dan disiplin kerja berpengaruh positif dan signifikan terhadap kinerja karyawan hal ini dapat dibuktikan oleh nilai $F_{\text {hitung }} 31,222>F_{\text {tabel }} 3,11$ dengan siginifikan $0,000<0,05$ dan nilai $R$ nilai koefisien determinasi sebesar 43,2\%.
\end{abstract}

Kata Kunci : Lingkungan Kerja, Disiplin Kerja, Kinerja Karyawan

\begin{abstract}
This study aims to determine the effect of the work environment and work discipline both partially and simultaneously on employee performance at PT. Caturkarda Depo Serpong Tangerang Building. The method used in this study uses associative quantitative approach while the sample used in this study were 85 respondents. Data collection techniques by means of questionnaires, data analysis techniques with validity, reliability, classic assumption tests, multiple regression analysis, hypothesis testing, $F_{\text {test }} F_{\text {tesp }}$ and coefficient of determination. The results showed that the work environment had a positive and significant effect on employee performance, this can be proven by the regression value of $0.091 X_{1} . T_{\text {count }}$ value of 3.086> $t_{\text {table }} 1.989$ with a significance of 0.003 $<0.05$. And the coefficient of determination of $28.5 \%$. Work discipline has a positive and significant effect on employee performance, this can be proven by the regression value of $0.173 X_{2} . T_{\text {value }} 4.612>t_{\text {table }} 1.989$ with a significant $0.000<0.05$. And the coefficient of determination $36.6 \%$. Simultaneously the work environment and
\end{abstract}


work discipline have a positive and significant effect on employee performance. This can be proven by the value of $F_{\text {count }} 31.222>F_{\text {table }} 3.11$ with a significance of $0.000<0.05$ and the $R_{\text {value }}$ of the coefficient of determination of $43.2 \%$

Keywords : Work Environment, Work Discipline, Employee Performance

\section{PENDAHULUAN}

Manajemen sumberdaya manusiamerupakan bagian dari manajemen keorganisasian yang memfokuskan diri pada unsur sumber daya manusia atau bisa di katakan suatu proses yang terdiri dari perencanaan, pengorganisasian, pemimpin dan pengendalian kegiatan sumber daya manusia dan sumber daya manusia lainnya untuk mencapai tujuan yang telah ditetapkan.

Handoko (2008:3) mengemukakan bahwa manajemen sebagai suatu cabang ilmu pengetahuan yang berusaha secara sistematis untuk memahami mengapa dan bagaimana manusia bekerja bersama untuk mencapai tujuan dan membuat sistem kerja sama ini lebih baik bermanfaat bagi manusia.

Pentingnya sebuah motivasi bagi karyawan perusahaan, bisa dilihat dan dinilai sejauh mana tanggung jawab yang dilaksanakan dan dicapai pada setiap karyawan. Setiap karyawan diharapkan memiliki motivasi yang tinggi untuk mendukung kemajuan sebuah perusahaan.

Menurut Sri Widodo (2016:291), motivasi merupakan kondisi atau energi yang mengerakkan diri pegawai yang terarah atau tertuju untuk mencapai tujuan oraganisasi. Sedangkan menurut Veithzal Rifai (2003:455) motivasi adalah serangkaian sikap dan nilai-nilai yang mempengaruhi individu untuk mencapai hal yang spesifik sesuai dengan tujuan individu. Sikap dan nilai tersebut merupakan sesuatu kekuatan yang mampu mendorong individu untiuk bertingkah laku mencapai tujuan.

Sementara itu menurut Mangkunegara (2008:54), stres merupakan sesuatuyang menyangkut interaksi antara individu dan lingkungan yaitu interaksi antara simultan dan respon. Jadi stres adalah konsekuensi setiap tindakan dan situasi lingkungan yang menimbulkan tuntutan psikologi dan fisik yang berlebihan. Stres kerja akan muncul bila terdapat kesenjangan antara kemampuan individu dengan tuntutan-tuntutan dari pekerjaannya.

Mengingat keberhasilan suatu perusahaan tak lepas dari kinerja karyawan. Salah satu yang mempengaruhi tingkat keberhasilan perusahaan itu sendiri adalah kinerja karyawan. Memiliki karyawan dengan kinerja yang baik merupakan dambaan setiap perusahaan. Menurut Hasibuan (2010:172) "Kinerja karyawan adalah hasil kerja karyawan dilihat dari aspek kualitas, kuantitas, waktu kerja, dan kerja sama untuk mencapai tujuan yang sudah ditetapkan organisasi,Semuanya akan berjalan dengan optimal jika di dukung dengan sumber daya manusia yang mumpuni dan berkualitas, Nawawi (2006:63) adalah kinerja dikatakan tinggi apabila suatu target kerja dapat diselesaikan pada waktu yang tepat atau tidak melampui batas waktu yang disediakan. Kinerja menjadi rendah jika diselesaikan melampui batas waktu yang disediakan atau sama sekali tidak terselesaikan".

Berdasarkan hasil pengamatan penulis, motivasi karyawan CV Muslim Indonesia mengalami penurunan hal ini bisa dilihat dari balas jasa yang dirasakan masih kurang dimana karyawan merasa gaji yang diterima belum dapat mencukupi kebutuhan fisiologis (sandan, pangan, papan) karyawan dan keluarganya karna setiap bulannya masih banyak karyawan yang membayar hutang untuk mencukupi kebutuhan sehari-hari. Untuk customer service facebook, mereka hanya mendapatkan gaji pokok sedangkan karyawan yang lain hanya mendapatkan bonus yang tidak sebanding dengan apa yang sudah dikerjakan.

Kebutuhan rasa aman juga belum sepenuhnya di peroleh, bisa dilihat dari tunjangan kesehatan yang belum sesuai, tidak adanya asuransi kesehatan dan ketenagakerjaan. Hal ini menyebabkan motivasi karyawan menurun sehingga absensi meningkat dimana banyaknya karyawan yang datang terlambat saat masuk kerja, sering 
izin dengan berbagai alasan, tidak menyelesaikan pekerjaan secara tepat waktu, dan kurang bergairah dalam berprestasi.

Selain motivasi kerja yang rendah, karyawan CV Muslim Galeri Indonesia juga memiliki masalah stres kerja. Semua karyawan tersebut pasti memiliki permasalahan stres yang berbeda-beda seperti customer service facebook yang memiliki tugas untuk melayani customer yang ingin membeli produk dari muslim galeri indonesia. Sistem dari penjualan online di Muslim Galeri Indonesia yakni, dikirim dulu baru transfer. Jadi ketika barang sudah sampai customer bisa melakukan pembayaran melalui transfer. Sistem tersebut membuat customer service facebook merasa terbebani sehingga mengalami stres dan tekanan, karena banyak pembeli yang tidak amanah dengan tidak mau membayar barang yang sudah dipesan.

Waktu kerja yang tidak tentu karena setiap bulan customer service facebook harus menagih pembayaran terhadap pembeli ada yang berhasil namun tak sedikit pula yang gagal. Sehingga terkadang karyawan facebook harus lembur hingga jam 7 malam untuk menagih customer yang tidak mau membayar. Tak hanya customer service facebook saja yang waktu kerjanya tidak tentu, bagian IT juga mengalami hal serupa, bahkan lebih parah karna terkadang harus lembur hingga jam 12 malam untuk membuat rakitan produk yang dijual. Customer service harus berpikir langkah apa yang harus di tempuh agar konsumen mau membayar barang yang sudah dibeli karena jika pembeli tidak mau membayar otomatis customer service yang harus menanggung sejumlah modal yang dikeluarkan.

Kuantitas kerja karyawan juga mengalami penurunan dimana masih ditemukan karyawan yang suka menunda-nunda pekerjaan sehingga pekerjaannya menumpuk, target waktu yang diberikan tidak dapat dipenuhi. Karyawan juga belum bisa mengemban tanggung jawab karena berdasarkan hasil pengamatan penulis, masih banyak karyawan yang memanfaatkan jam kerja dengan main game, nonton youtube, bermain sosial media, mengobrol saat jam kerja, bahkan waktu istirahat yang suka diperpanjang.
Mengenai kebersamaan dalam kerjasama antar karyawan, masih individualis dan kurang peduli, tetapi tidak semuanya demikian. Karyawan juga kurang memiliki inisiatif, semisal ada masalah yang dihadapi mereka harus menunggu instruksi dari atasan hal apa yang akan mereka lakukan. Belum berani memberikan ide atau gagasan

Berdasarkan uraian latar belakang masalah tersebut, penulis merasa tertarik untuk melakukan penelitian Pengaruh Motivasi dan Streskerja Kerja Terhadap Kinerja Karyawan Pada CV Muslim Galeri Indonesia.

\section{METODE}

\section{Metode Penelitian}

Metode yang digunakan dalam penelitian ini adalah Asosiatif, menurut Sugiyono (2015:44) yaitu "penelitian yang bertujuan untuk mengetahui pengaruh atau hubungan antara dua variabel lebih, Penelitian Asosiatif mempunyai tingkatan yang lebih tinggi bila dibandingkan dengan deskriptif dan komparitif, lebih lanjut Sugiyono (2015:44) menjelaskan "dengan penelitian Asosiatif maka dibangun suatu teori yang berfungsi untuk menjelaskan, meramalkan dan mengontrol suatu gejala”.

\section{Tempat Penelitian}

Tempat penelitian ini dilakukan pada di CV. Muslim Galeri Indonesia Jl. Cemara Mas blok C1 No 63, Bambu Apus, Pamulang, Tangerang Selatan. Waktu penelitian ini berlangsung pada bulan Juli 2019 s/d Januari 2020.

\section{Jenis Data Penelitian}

Menurut pendapat Hadi (1986:4) "Metode research sebagaimana diketahui sekarang yaitu memberikan garis-garis yang sangat keras, maksudnya adalah agar menjaga pengetahuan yang ingin dicapai dari suatu research mempunyai karya ilmiah yang setinggi-tingginya. Menurut Wardiyanto dan M.Baiquni (2011:28) data primer adalah "informasi yang diperoleh dari sumbersumber primer yaitu informasi dari tangan-tangan pertama atau nara sumber". Data Sekunder adalah informasi yang diperoleh secara tidak langsung 
dari nara sumber, tetapi dari pihak ketiga.

\section{Metode Pengumpulan Data \\ Observasi}

Menurut Istijanto (2005:60), observasi adalah "pengumpulan data yang dijalankan dengan mengamati dan mencatat pola perilaku orang, obyek atau kejadaian-kejadian melalui secara sistematik. Menurut Sugiyono (2015:141) observasi merupakan suatu proses yang tersusun dari berbagai proses sehingga diperoleh data berdasarkan fakta mengenai dunia kenyataan yang diperoleh melalui observasi". Nasution (2009) menyatakan bahwa, "observasi adalah dasar semua ilmu pengetahuan. Para ilmuwan hanya dapat bekerja berdasarkan data, yaitu fakta mengenai dunia kenyataan yang diperoleh melalui observasi”.

\section{Wawancara}

Menurut Sugiyono (2015:133), "wawancara merupakan metode yang digunakan untuk memperoleh informasi secara langsung, mendalam, tidak terstruktur, dan individual, Menurut Emzir (2010: 50) "wawancara ialah proses komunikasi atau interaksi untuk mengumpulkan informasi dengan cara tanya jawab antara peneliti dengan informan atau subjek penelitian", Wawancara adalah percakapan dengan maksud tertentu. Percakapan itu dilakukan oleh dua pihak, pewawancara (interviewer) yang mengajukan pertanyaan dan terwawancara (interviewee) yang memberikan jawaban atas pertanyaaan itu. Maksud mengadakan wawancara, seperti ditegaskan oleh Sementara Suharsimi (1985:266)".

\section{Angket/Kuesioner}

Menurut Sugiyono (2015:142) "kuesioner merupakan teknik pengumpulan data yang efisien apabila peneliti tahu dengan siapa variabel akan diukur dan tahu apa yang bisa diharapkan dari responden. Angket merupakan teknik pengumpulan data yang dilakukan dengan cara memberikan seperangkat pertanyaan atau pernyataan tertulis kepada responden untuk dijawabnya (Sugiyono, 2014: 142), Sementara Suharsimi (1995: 136-138) mengatakan angket tertutup adalah angket yang disajikan dalam bentuk sedemikian rupa sehingga responden tinggal memberikan tanda centang $(\sqrt{ })$ pada kolom atau tempat yang sesuai, Menurut Walgito (199;35-37) angket adalah metode pengumpulan data penelitian dengan menggunakan daftar pertanyaan yang harus dijawab oleh responden, Bentuk angketnya dapat dibedakan menjadi tiga yaitu angket tertutup, angket terbuka, dan angket tertutup-terbuka. Angket tertutup merupakan angket yang menyediakan alternatif jawaban atas pertanyaan yang diberikan sehingga responden tidak mempunyai kebebasan untuk menjawab pertanyaan di luar alternatif jawaban yang disediakan adalam angket tersebut. Angket terbuka adalah angket yang tidak menyediakan jawaban atas pertanyaan yang diberikan, sehingga responden mempunyai kebebasan memberikan jawaban. Angket tertutup-terbuka merupakan kombinasi dari angket tertutup dan angket terbuka. "Dalam penelitian ini kuesioner yang dibuat berupa pernyataan dimana jawabannya mengacu pada skala Likert".

\section{Studi Kepustakaan}

Menurut Sugiyono, studi kepustakaan berkaitan dengan kajian teoritis dan referensi lain yang berkaitan dengan nilai, budaya dan norma yang berkembang pada situasi sosial yang diteliti, selain itu studi kepustakaan sangat penting dalam melakukan penelitian, hal ini dikarenakan penelitian tidak akan lepas dari literatur-literatur Ilmiah (Sugiyono, $2012: 291$ ). Menurut Sugiyono (2015:308), "Data sekunder adalah data yang diperoleh secara tidak langsung yang memberikan data kepada pengumpul data, misalnya orang lain atau dokumen".

\section{Uji Instrumen}

\section{Uji Validitas}

Validitas adalah "suatu ukuran yang menunjukkan tingkat-tingkat kevalidan atau kesahihan suatu instrumen. Menurut Arikunto (2015:116"), Validitas menurut Sugiyono (2016:177) "menunjukkan derajat ketepatan- 69 antara data yang sesungguhnya terjadi pada objek dengan data yang dikumpulkan oleh peneliti untuk mencari 
validitas sebuah item, kita mengkorelasikan skor item dengan total item-item tersebut, Jika koefisien antara item dengan total item sama atau diatas 0,3 maka item tersebut dinyatakan valid, tetapi jika nilai korelasinya dibawah 0,3 maka item terebut dinyatakan tidak valid”.

\section{Uji Reliabilitas}

Menurut Ghozali (2012:78), "Reliabilitas adalah tingkat kehandalan kuesioner, Kuesioner yang reliable adalah kuesioner yang apabila dicoba secara berulang-ulang kepada kelompok yang sama akan menghasilkan data yang sama dengan asumsi tidak terdapat perubahan psikologis pada responden", Uji reliabilitas adalah" sejauh mana hasil pengukuran dengan menggunakan objek yang sama akan menghasilkan data yang sama (Sugiyono, 2012 : 177). Uji realianilitas kuesioner dalam penelitian digunakan metode split half item tersebut dibagi menjadi dua kelompok yaitu kelimpok item ganjil dan kelompok item genap Kemudian masing-masing kelompok skor tiap itemnya dijumlahkan sehingga menghasilkan skor total. Apabila korelasi 0,7 maka dikatakan item tersebut memberikan tingkat reliabel yang cukup, sebaliknya apabila nilai korelasi dibawah 0,7 maka dikatakan item tersebut kurang reliabel”.

\section{Uji Asumsi Klasik}

\section{Uji Normalitas}

Menurut Ghozali (2012:73) uji normalitas digunakan untuk melihat apakah nilai residual terdistribusi normal atau tidak. Model regresi yang baik adalah memiliki nilai residual yang terdistribusi normal. Jadi uji normalitas bukan dilakukan pada masing-masing variabel tetapi pada nilai residualnya. Untuk mendeteksi apakah residual berdistribusi normal atau tidak yaitu dengan melihat normal probability plot dan one sampel kolmogrof smirnov test yang membandingkan distribusi kumulatif dari distribusi normal. Normalitas pada probability plot dapat dideteksi dengan melihat penyebaran dan (titik) pada sumbu diagonal dari grafik. Jika ada (titik) menyebar disekitar garis diagonal maka menunjukkan pola distribusi normal dan pada one sampel kolmogrof smirnov test nilai Asymp.
Sig 2 (tailed) nilai keakuratan 95\% berarti nilai signifikan/Sig 0,05, nilai pada uji ini harus diatas 0,05 yang mengindikasikan bahwa model regresi memenuhi asumsi normal.

MenurutSugiyono (2015:239), "uji normalitas digunakan untuk mengkaji kenormalan variabel yang diteliti apakah data tersebut berdistribusi normal atau tidak". Hal tersebut penting karena bila data setiap variabel tidak normal, maka pengujian hipotesis tidak bisa menggunakan statistik parametrik pengujian secara visual dapat juga dilakukan dengan metode grafik normal Probability Plots berikut:

1. Jika data menyebar disekitar garis diagonal dan mengikuti arah garis diagonal, maka dapat disimpulkan bahwa model regresi memenuhi asumsi normalitas".

2. Jika data menyebar jauh dari garis diagonal dan tidak mengikuti arah garis diagonal, maka dapat disimpulkan bahwa model regresi tidak memenuhi asumsi normalitas".

\section{Uji Multikolinearitas}

"Untuk mendeteksi ada tidaknya multikolinieritas dapat dilihat dari besaran Variance Inflation Factor (VIF) dan Tolerance Pedoman suatu model regresi yang bebas multikolinieritas adalah mempunyai angka tolerance mendekati 1 Batas VIF adalah 10, jika nilai VIF dibawah 10, maka tidak terjadi gejala multikolinieritas (Gujarati, 2012:432)”. Menurut Ghozali (2012:82), "uji multikolinearitas bertujuan untuk menguji apakah model regresi ditemukan adanya korelasi antar variabel bebas (independen)". Model regresi yang baik seharusnya tidak terjadi korelasi di antara variabel independen. Jika variabel independen saling berkorelasi, maka variabel-variabel ini tidak ortogonal. Variabel ortogonal adalah variabel independen yang nilai korelasi antar sesama variabel independen sama dengan nol.

1. "Besarnya Variabel Inflation Factor/VIF pedoman suatu model regresi yang bebas Multikolineritas yaitu nilai VIF $<10$ ".

2. "Besarnya Tolerance pedoman suatu model regresi yang bebas Multikolineritas yaitu nilai Tolerance $>0,1$ ". 


\section{Uji Heteroskedastisitas}

Menurut Gujarati (2012:406) "untuk menguji ada tidaknya heteroskedastisitas digunakan uji-rank Spearman yaitu dengan mengkorelasikan variabel independen terhadap nilai absolut dari residual (error). Untuk mendeteksi gejala uji heteroskedastisitas, maka dibuat persamaan regresi dengan asumsi tidak ada heteroskedastisitas kemudian menentukan nilai absolut residual, selanjutnya meregresikan nilai absolute residual diperoleh sebagai variabel dependen serta dilakukan regresi dari variabel independen." Menurut Ghozali (2012:83), "tujuan dari pengujian ini adalah untuk menguji apakah dalam model regresi terjadi ketidak samaan variance dari residual satu pengamatan ke pengamatan lainnya". Model regresi yang baik adalah yang homoskesdastisitas, yakni variance dari residual satu pengamatan ke pengamatan lain bersifat tetap untuk mendiktesikannya atau dengan cara melihat grafik perhitungan antara nilai prediksi variabel tingkat (zpred) dengan residual (srecid).

1. Jika ada pola tertentu, seperti titik-titik yang ada membentuk suatu pola yang teratur (bergelombang melebar kemudian menyempit) maka terjadi heteroskedastisitas".

2. "Jika tidak ada pola yang jelas seperti titiktitik menyebar diatas dan dibawah angka 0 pada sumbu Y, maka hal ini mengindikasikan tidak terjadi heteroskedastisitas".

\section{Uji Lineritas}

"Menurut Sugiyono (2015:323), uji linieritas digunakan untuk mengetahui hubungan dari variabel independen dengan variabel dependen apakah linier atau tidak". Jika terdapat hubungan yang linier maka digunakan analisis regresi linier. Sedangkan jika tidak terdapat hubungan linier antara dua variabel tersebut maka digunakan analisis regresi non-linier".

1. "Jika nilai $s i g>0,05$, maka hubungan antara variabel independent Dengan variabel dependent adalah linier".

2. "Jika nilai $s i g<0,05$, maka hubungan antara variabel independent Dengan variabel dependent adalah tidak linier".

\section{Regresi Linier Berganda}

Metodeode analisis yang digunakan adalah model regresi linier berganda. Menurut Sugiyono (2015:277) bahwa "Analisis regresi linier berganda bermaksud meramalkan bagaimana keadaan (naik turunnya) variabel dependen (kriterium), bila dua atau lebih variabel independen sebagai faktor prediator dimanipulasi (dinaik turunkan nilainya). Jadi analisis regresi berganda akan dilakukan bila jumlah variabel independennya minimal 2", "Regresi linier sederhana didasarkan pada hubungan fungsional ataupun kausal satu variabel bebas dengan satu variabel terikat. Menunjukkan angka peningkatan ataupun penurunan variabel terikat yang didasarkan pada variabel bebas", Arif. Ramdhani (2011). Jadi analisis regresi berganda akan dilakukan bila jumlah variabel independennya minimal 2". Adapun bentuk persamaan regresi linier berganda sebagai berikut:

\section{Pengujian Hipotesis \\ Uji Signifikan Parsial (Uji t)}

Menurut Ghozali (2012:84), "Pengujian hipotesis secara parsial, dapat diuji dengan menggunakan rumus uji t, Uji t pada dasarnya menunjukkan seberapa jauh pengaruh satu variable penjelas/independen secara individual dalam menerangkan variasi variable independen". Menurut Sugiyono (2012:99) "uji persial (uji t) digunakan untuk menguji hipotesis secara persial guna menunjukkan pengaruh tipe variabel independen secara sendiri terhadap variabel dependen, tingkat signifikansi yang dipilih dalam penelitian ini adalah 0,05 atau (5\%) artinya kemungkinan besar hasil penarikan kesimpulan mempunyai probabilitas $95 \%$ atau toleransi kesalahan sebesar 5\%. Hubungan variabel independen dengan variabel dependen, akan diuji dengan uji t (menguji signifikansi korelasi product moment)".

\section{Uji Signifikan Simultan (Uji F)}

Uji F pada dasarnya menunjukkan apakah semua variabel independen atau bebas yang dimasukkan dalam model mempunyai pengaruh secara bersama-sama terhadap variabel dependen atau terikat. Pada pengujian simultan akan diuji 
pengaruh keempat variabel independen secara bersama-sama terhadap variabel dependen. "Uji statistik yang digunakan pada pengujian simultan adalah Uji $\mathrm{F}$ atau yang biasa disebut dengan Analysis of Varian (ANOVA). Pengujian Uji F menurut Sugiyono (2012:192), Pada pengujian ini juga menggunakan tingkat signifikansi sebesar $5 \%$ atau $0,05 \%$.

Sementara itu nilai $\mathrm{F}_{\text {hitung }}$ dapat ditentukan dengan rumus sebagai berikut:

$$
t=\frac{r \sqrt{n-2}}{\sqrt{1-r^{2}}}
$$

Dimana:

$$
\begin{aligned}
& \mathrm{t}=\text { Nilai } \mathrm{t}_{\text {hitung }} \\
& \mathrm{r}=\text { Nilai koefisien korelari } \\
& \mathrm{n}=\text { Jumlah data pengamatan }
\end{aligned}
$$

\section{Uji Koefisien Determinasi}

Algifari (2010: 32). "Koefisien Determinasi pada intinya mengukur seberapa jauh kemampuan model dalam menerangkan variasi variabel terikat nilai Koefisien Determinasi atau antara 0 dan 1 nilai $\mathrm{R}^{2}$ yang terikat berarti kemampuan variabelvariabel bebas dalam menjelaskan variasi sangat terbatas nilai yang mendekati berarti variabel bebas menggmbarkan hampir semua informasi yang dibutuhkan untuk memprediksi variasi variabel terikat", Menurut Ghozali (2012:102) "koefisien determinasi $\left(\mathrm{R}^{2}\right)$ bertujuan untuk mengetahui seberapa besar kemampuan variabel independen menjelaskan variabel dependen. Dalam output SPSS, koefisien determinasi terletak pada tabel Model Summary dan tertulis Adjusted R Square, Nilai $\mathrm{R}^{2}$ sebesar 1 , berarti fluktuasi variabel dependen seluruhnya dapat dijelaskan oleh variabel independen dan tidak ada faktor lain yang menyebabkan fluktuasi variabel dependen. Jika nilai $\mathrm{R}^{2}$ berkisar antara 0 sampai dengan 1 , berarti semakin kuat kemampuan variabel independen dapat menjelaskan fluktuasi variabel terikat".

Rumus yang digunakan adalah sebagai berikut:

$$
\mathrm{KD}=\mathrm{r}^{2} \mathrm{X} 100 \%
$$

Dimana:

$\mathrm{KD}=$ Koefisien Determinasi

$r^{2}=$ Kuadrat Koefisien Korelasi

\section{HASIL dan PEMBAHASAN}

Hasil

Berdasarkan hasil pengumpulan data baik primer maupun sekunder, diperoleh gambaran hasil penelitian. Data yang terkumpul kemudian diolah sesuai jumlah responden yang telah ditetapkan sebelumnya, jumlah angket yang disebarkan kepada responden sebanyak 85 angket dan telah dikembalikan seluruhnya. Setelah data angket terkumpul ternyata secara keseluruhan memenuhi syarat untuk dianalisis, dan diin-

\begin{tabular}{|c|c|c|c|c|c|}
\hline \multicolumn{6}{|c|}{ Tabel 1. Hasil Uji Validitas } \\
\hline $\begin{array}{c}\text { Item } \\
\text { Pertanyaan }\end{array}$ & $\mathbf{r}_{\text {hitung }}$ & $r_{\text {hitung }}$ & $r_{\text {hitung }}$ & $r_{\text {tebel }}$ & Keterangar \\
\hline 1 & 0,626 & 0,852 & 0,544 & 0,240 & Valid \\
\hline 2 & 0,364 & 0,775 & 0,448 & 0,240 & Valid \\
\hline 3 & 0,787 & 0,861 & 0,582 & 0,240 & Valid \\
\hline 4 & 0,555 & 0,416 & 0,408 & 0,240 & Valid \\
\hline 5 & 0,620 & 0,907 & 0,379 & 0,240 & Valid \\
\hline 6 & 0,787 & 0,920 & 0,447 & 0,240 & Valid \\
\hline 7 & 0,598 & 0,796 & 0,391 & 0,240 & Valid \\
\hline 8 & 0,634 & 0,782 & 0,460 & 0,240 & Valid \\
\hline 9 & 0,735 & 0,878 & 0,377 & 0,240 & Valid \\
\hline 10 & 0,573 & 0,871 & 0,253 & 0,240 & Valid \\
\hline
\end{tabular}
terprestasikan guna memecahkan permasalahan yang telah dirumuskan.

\section{Uji Instrument \\ Uji Validitas}

Hasil yang diperoleh nilai $\mathrm{r}_{\text {hitung }}>\mathrm{r}_{\text {tabel }} 0,240$, dapat disimpulkan bahwa semua item pernyataan Valid.

\section{Uji Reliabilitas}

\begin{tabular}{|l|c|c|c|}
\hline \multicolumn{1}{|c|}{ Tabel 2. Hasil Uji Reliabilitas } \\
\hline \multicolumn{1}{|c|}{ Variabel } & Reability Coefficients & Alpha & Keterangan \\
\hline Motivasi $\left(X_{1}\right)$ & 10 Item & 0,764 & Reliabel \\
\hline Stres Kerja $\left(X_{2}\right)$ & 10 Item & 0,712 & Reliabel \\
\hline Kinerja $(Y)$ & 10 Item & 0,719 & Reliabel \\
\hline \multicolumn{4}{|c|}{ Sumber: Data dari Penulis 2020 } \\
\hline
\end{tabular}

Dapat diketahui bahwa masing-masing variabel $\mathrm{X}_{1}, \mathrm{X}_{2}$ danY nilai Cronbach Alpha $\geq 0,60$. Sehingga semua butir pertanyaan dapat dipercaya dan dapat digunakan untuk penelitian selanjutnya. 


\section{Uji Asumsi Klasik}

\section{Hasil Uji Normalitas Data}

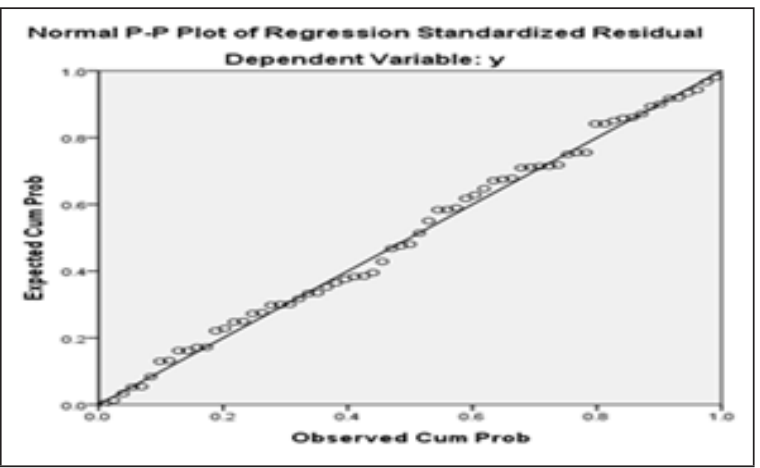

Gambar 1. Hasil Uji Normalitas Data

"Melihat diagram probabilitas normal di atas, dapat disimpulkan bahwa diagram probabilitas normal, sehingga dapat disimpulkan dapat diketahui penelitian ini berdistribusi normal".

\section{Uji Multikolineritas}

\begin{tabular}{|c|c|c|c|c|c|c|c|c|}
\hline \multicolumn{9}{|c|}{ Tabel 3. Hasil Uji Multikolinieritas } \\
\hline \multicolumn{9}{|c|}{ Coefficients $^{\mathrm{a}}$} \\
\hline \multirow{2}{*}{\multicolumn{2}{|c|}{ Model }} & \multicolumn{2}{|c|}{$\begin{array}{l}\text { Unstandardized } \\
\text { Coefficients }\end{array}$} & \multirow{2}{*}{$\begin{array}{l}\text { Standard- } \\
\text { ized Coef- } \\
\text { ficients } \\
\text { Beta }\end{array}$} & \multirow{2}{*}{$t$} & \multirow{2}{*}{ Sig. } & \multicolumn{2}{|c|}{$\begin{array}{l}\text { Collinearity } \\
\text { Statistics }\end{array}$} \\
\hline & & B & $\begin{array}{l}\text { Std. } \\
\text { Error }\end{array}$ & & & & $\begin{array}{l}\text { Toler- } \\
\text { ance }\end{array}$ & VIF \\
\hline \multirow{3}{*}{1} & (Constant) & 12,054 & 3,337 & & 3,612 & ,001 & & \\
\hline & Motivasi & ,378 & ,087 & .489 & 4,357 & ,000 & .576 & 1,735 \\
\hline & Stres Kerja &, 328 & 118 & .311 & 2,772 & ,007 & .576 & 1,735 \\
\hline
\end{tabular}

Nilai toleransi dan SWF untuk masingmasing variabel: Nilai toleransi untuk variabel kontrol Lingkungan kerja $\left(\mathrm{X}_{1}\right)$ adalah 0,576> 0,10 , berarti Variabel tidak terjadi dengan gejala multicolor. Nilai toleransi variabel $\left(\mathrm{X}_{2}\right)$ adalah $0,5761>0,10$, yang berarti tidak terjadi korelasi

\section{Uji Lineritas}

\begin{tabular}{|c|c|c|c|c|c|c|}
\hline \multicolumn{7}{|c|}{$\begin{array}{l}\text { Tabel 4. Hasil Uji Regresi Linier Sederhana } \\
\text { Motivasi (X) Terhadap Kinerja (Y) }\end{array}$} \\
\hline \multicolumn{7}{|c|}{ Coefficients ${ }^{\mathrm{a}}$} \\
\hline \multirow{2}{*}{\multicolumn{2}{|c|}{ Model }} & \multicolumn{2}{|c|}{$\begin{array}{l}\text { Unstandardized } \\
\text { Coefficients }\end{array}$} & \multirow{2}{*}{\begin{tabular}{|c|}
$\begin{array}{c}\text { Standardized } \\
\text { Coefficients }\end{array}$ \\
Beta \\
\end{tabular}} & \multirow{2}{*}{$t$} & \multirow{2}{*}{ Sig. } \\
\hline & & B & $\begin{array}{l}\text { Std. } \\
\text { Error }\end{array}$ & & & \\
\hline \multirow{2}{*}{1} & (Constant) & 18,481 & 2,520 & & 7,334 & ,000 \\
\hline & Motivasi & .534 & .069 & ,692 & 7,728 & ,000 \\
\hline \multicolumn{7}{|c|}{ a. Dependent Variable: Kinerja } \\
\hline & & & & \multicolumn{3}{|c|}{ Sumber data: Hasil olahan data SPSS } \\
\hline
\end{tabular}

Diketahui bahwa nilai signifikansi lingkungan kerja $\left(\mathrm{X}_{1}\right)$ 0,18,41 >0,05 sehingga dapat disimpulkan bahwa hubungan antara variabel lingkungan kerja dengan kinerja karyawan adalah linier.

\begin{tabular}{|c|c|c|c|c|c|c|}
\hline \multicolumn{7}{|c|}{$\begin{array}{l}\text { Tabel 5. Hasil Uji Regresi Linier Sederhana } \\
\text { Stres Kerja (X) Terhadap Kinerja (Y) }\end{array}$} \\
\hline \multicolumn{7}{|c|}{ Coefficients $^{a}$} \\
\hline \multirow{2}{*}{\multicolumn{2}{|c|}{ Model }} & \multicolumn{2}{|c|}{$\begin{array}{l}\text { Unstandardized } \\
\text { Coefficients }\end{array}$} & \multirow{2}{*}{$\begin{array}{c}\text { Standardized } \\
\text { Coefficients } \\
\text { Beta }\end{array}$} & \multirow{2}{*}{$\mathrm{t}$} & \multirow{2}{*}{ Sig. } \\
\hline & & B & $\begin{array}{l}\text { Std. } \\
\text { Error }\end{array}$ & & & \\
\hline \multirow{2}{*}{1} & (Constant) & 13,329 & 3,756 & & 3,549 & ,001 \\
\hline & Stres Kerja &, 664 &, 102 &, 630 & 6,538 &, 000 \\
\hline \multicolumn{7}{|c|}{ a. Dependent Variable: Kinerja } \\
\hline & & & & \multicolumn{3}{|c|}{ Sumber data: Hasil olahan data SPSS } \\
\hline
\end{tabular}

Dapat dijelaskan bahwa, persamaan linier sederhana $\mathrm{Y}=\mathrm{a}+\mathrm{b}(\mathrm{x})$ adalah $\mathrm{Y}=13,329+0,664$ $\left(\mathrm{X}_{2}\right)$. Persamaan regresi ini dapat disimpulkan bahwa, terdapat pengaruh positif $\left(\mathrm{X}_{1}\right)$ Terhadap Kinerja (Y)

\section{Regresi Linier Berganda}

\begin{tabular}{|c|c|c|c|c|c|c|}
\hline \multicolumn{7}{|c|}{ Tabel 6. Hasil Uji Regresi Linier Berganda } \\
\hline \multicolumn{7}{|c|}{ Coefficients $^{a}$} \\
\hline \multirow{2}{*}{\multicolumn{2}{|c|}{ Model }} & \multicolumn{2}{|c|}{$\begin{array}{l}\text { Unstandardized } \\
\text { Coefficients }\end{array}$} & \multirow{2}{*}{$\begin{array}{c}\begin{array}{c}\text { Standardized } \\
\text { Coefficients }\end{array} \\
\text { Beta }\end{array}$} & \multirow{2}{*}{$\mathrm{t}$} & \multirow{2}{*}{ Sig. } \\
\hline & & B & $\begin{array}{l}\text { Std. } \\
\text { Error }\end{array}$ & & & \\
\hline \multirow{3}{*}{1} & (Constant) & 12,054 & 3,337 & & 3,612 &, 001 \\
\hline & Motivasi & .378 & 087 & .489 & 4,357 &, 000 \\
\hline & Stres Kerja & .328 &, 118 &, 311 & 2,772 &, 007 \\
\hline \multicolumn{7}{|c|}{ a. Dependent Variable: Kinerja } \\
\hline & & & & \multicolumn{3}{|c|}{ Sumber data: Hasil olahan data SPSS } \\
\hline
\end{tabular}

Berdasarkan hasil perhitungan tersebut maka dapat diperoleh persamaan regresi linier ber-

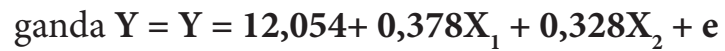

Di mana:

$\mathrm{X}_{1}=$ lingkungan kerja

$\mathrm{X}_{2}=$ disiplin kerja

$\mathrm{Y}=$ Kinerja karyawan

Jika nilai $\mathrm{X}_{1}$ dan $\mathrm{X}_{2}=0$ akan diperoleh $\mathrm{Y}=$ 12,054

1. Konstanta sebesar 23,683 artinya jika lingkungan kerja dan disiplin kerja, bernilai nol 
atau tidak meningkat maka kinerja karyawan akan tetap bernilai sebesar 12,054.

2. Nilai regresi $0,378 \mathrm{X}_{1}$ artinya apabila variabel lingkungan kerja $\left(\mathrm{X}_{1}\right)$ meningkat sebesar 1 satuan dengan asumsi variabel disiplin kerja $\left(\mathrm{X}_{2}\right)$ tetap, maka kinerja karyawan $(\mathrm{Y})$ akan meningkat sebesar 0,378 satuan.

Nilai regresi $0,328 \mathrm{X} 2$ artinya apabila variabel disiplin kerja $\left(\mathrm{X}_{2}\right)$ meningkat sebesar 1 satuan, dengan asumsi variabel lingkungan kerja $\left(\mathrm{X}_{1}\right)$ tetap, maka kinerja karyawan (Y) akan meningkat sebesar 0,328 satuan.

\section{Uji Hipotesis}

\section{Uji Hipotesis Parsial (uji $\mathbf{t}_{\text {hitung }}$ )}

\begin{tabular}{|c|c|c|c|c|c|c|}
\hline \multicolumn{7}{|c|}{ Tabel 7. Hasil Uji t Variabel Motivasi } \\
\hline \multirow{2}{*}{\multicolumn{2}{|c|}{ Model }} & \multicolumn{2}{|c|}{$\begin{array}{l}\text { Unstandardized } \\
\text { Coefficients }\end{array}$} & \multirow{2}{*}{$\begin{array}{c}\begin{array}{c}\text { Standardized } \\
\text { Coefficients }\end{array} \\
\text { Beta }\end{array}$} & \multirow{2}{*}{$\mathrm{t}$} & \multirow{2}{*}{ Sig. } \\
\hline & & B & $\begin{array}{l}\text { Std. } \\
\text { Error }\end{array}$ & & & \\
\hline \multirow{2}{*}{1} & (Constant) & 18,481 & 2,520 & & 7,334 &, 000 \\
\hline & Motivasi & .534 & .069 & ,692 & 7,728 &, 000 \\
\hline \multicolumn{7}{|c|}{ a. Dependent Variable: Kinerja } \\
\hline & & & & \multicolumn{3}{|c|}{ Sumber data: Hasil olahan data SPS } \\
\hline
\end{tabular}

Dapat diketahui bahwa nilai $t_{\text {hitung }}$ motivasi sebesar 7,728 $>\mathrm{t}_{\text {tabel }} 1,989$ dengan signifikan 0,000 $<0,05$ maka $\mathrm{H}_{0}$ ditolak dan $\mathrm{H}_{\mathrm{a}}$ diterima menandakan bahwa terdapat pengaruh yang positif dan signifikan.

\begin{tabular}{|c|c|c|c|c|c|c|}
\hline \multicolumn{7}{|c|}{ Tabel 8. Hasil Uji t Variabel Stres Kerja } \\
\hline \multicolumn{7}{|c|}{ Coefficients $^{\mathrm{a}}$} \\
\hline \multirow{2}{*}{\multicolumn{2}{|c|}{ Model }} & \multicolumn{2}{|c|}{$\begin{array}{l}\text { Unstandardized } \\
\text { Coefficients }\end{array}$} & \multirow{2}{*}{$\begin{array}{c}\begin{array}{c}\text { Standardized } \\
\text { Coefficients }\end{array} \\
\text { Beta }\end{array}$} & \multirow{2}{*}{$\mathrm{t}$} & \multirow{2}{*}{ Sig. } \\
\hline & & B & $\begin{array}{l}\text { Std. } \\
\text { Error }\end{array}$ & & & \\
\hline \multirow{2}{*}{1} & (Constant) & 13,329 & 3,756 & & 3,549 & ,001 \\
\hline & Stres Kerja & .664 & .102 & ,630 & 6,538 & ,000 \\
\hline \multicolumn{7}{|c|}{ a. Dependent Variable: Kinerja } \\
\hline & & & & \multicolumn{3}{|c|}{ Sumber data: Hasil olahan data SPSS } \\
\hline
\end{tabular}

Dapat diketahui bahwa nilai $\mathrm{t}_{\text {hitung }}$ stres kerja sebesar 6,58 $>\mathrm{t}_{\text {tabel }}$ 1,989 dengan signifikan 0,000 $<0,05$ maka $\mathrm{H}_{0}$ ditolak dan $\mathrm{H}_{\mathrm{a}}$ diterima menandakan bahwa terdapat pengaruh yang positif dan signifikan.
Uji Hipotesis Simultan (uji $F_{\text {hitung }}$ )

\begin{tabular}{|c|c|c|c|c|c|c|}
\hline \multicolumn{7}{|c|}{ Tabel 9. Hasil Ujif f } \\
\hline \multicolumn{7}{|c|}{ ANOVA $^{a}$} \\
\hline \multicolumn{2}{|c|}{ Model } & $\begin{array}{l}\text { Sum of } \\
\text { Squares }\end{array}$ & Df & $\begin{array}{l}\text { Mean } \\
\text { Square }\end{array}$ & $\mathrm{F}$ & Sig. \\
\hline \multirow{3}{*}{1} & Regression & 607.819 & 2 & 303.909 & 36.777 &, $000^{\circ}$ \\
\hline & Residual & 528.868 & 64 & 8.264 & & \\
\hline & Total & 1136.687 & 66 & & & \\
\hline \multicolumn{7}{|c|}{$\begin{array}{l}\text { a. Dependent Variable : Kinerja } \\
\text { b. Predictors: (Constant) : Stres Kinerja, Motivasi }\end{array}$} \\
\hline & & & & \multicolumn{3}{|c|}{ Sumber data: Hasil olahan data SPS } \\
\hline
\end{tabular}

Diperoleh nilai $\mathrm{F}_{\text {hitung }} 36,777>\mathrm{F}_{\text {tabel }} 3,140$ dengan siginifikan $0,000<0,05$ dengan demikian $\mathrm{H}_{0}$ ditolak dan $\mathrm{H}_{\mathrm{a}}$ diterima, artinya secara simultan terdapat pengaruh yang positif dan signifikan antara lingkungan kerja dan disiplin kerja terhadap kinerja karyawan.

\section{Pembahasan}

\section{Pengaruh Motivasi Kerja \\ Terhadap Kinerja Karyawan}

Berdasarkan Uji-t variabel Motivasi secara parsial terdapat pengaruh yang positif dan signifikan variabel Motivasi $\left(\mathrm{X}_{1}\right)$ terhadap Kinerja Karyawan (Y), hal ini dibuktikan dengan besarnya nilai $\mathrm{t}_{\text {hitung }}>\mathrm{t}_{\text {tabel }}$ yaitu 4,357>1,997 dan signifikansi

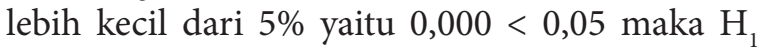
diterima dan $\mathrm{H}_{\mathrm{a}}$ ditolak.

\section{Pengaruh Stres Kerja}

\section{Terhadap Kinerja Karyawan}

Berdasarkan Uji-t variabel Stres Kerja secara parsial terdapat pengaruh yang positif dan signifikan variabel Stres Kerja $\left(\mathrm{X}_{2}\right)$ terhadap Kinerja Karyawan (Y), hal ini dibuktikan dengan besarnya nilai $\mathrm{t}_{\text {hitung }}>\mathrm{t}_{\text {tabel }}$ yaitu 2,772>1,997 dan signifikansi lebih kecil dari 5\% yaitu 0,000 <0,05 maka $\mathrm{H}_{2}$ diterima dan $\mathrm{H}_{\mathrm{a}}$ ditolak.

\section{Pengaruh Motivasi dan Stres Kerja Secara Bersama-Sama Terhadap Kinerja Karyawan}

Hasil pengujian terdapat pengaruh yang positif dan signifikan variabel Motivasi $\left(\mathrm{X}_{1}\right)$ dan Stres Kerja $\left(\mathrm{X}_{2}\right)$ secara bersama-sama terhadap kinerja karyawan $(\mathrm{Y})$ hal ini dibuktikan dengan besarnya nilai $\mathrm{F}_{\text {hitung }}>\mathrm{F}_{\text {tabel }}$ yaitu 36,777 > 3,140 dan tarif signifikan lebih kecil yaitu 0,000<,05 maka $\mathrm{H}_{2}$ diterima dan $\mathrm{H}_{\mathrm{a}}$ ditolak. 


\section{SIMPULAN}

Variabel Motivasi berpengaruh secara positif dan signifikan terhadap kinerja, hal ini terlihat dari nilai signifikan $(0,000)$ lebih besar dari 0,05 dan $\mathrm{t}_{\text {hitung }} 4,357>\mathrm{t}_{\text {tabel }}(1,997)$. Persamaan regresi linear sederhana $\mathrm{Y}=18,481+0,534\left(\mathrm{X}_{1}\right)$. Koefisien determinasi menunjukkan Motivasi $\left(\mathrm{X}_{1}\right)$ memberikan kontribusi terhadap kinerja (Y) sebesar $47,9 \%$ sedangkan sisanya $52,1 \%$ di luar penelitian ini.

Variabel stres kerja berpengaruh secara positif dan signifikan terhadap kinerja, hal ini terlihat dari nilai signifikan $(0,000)$ lebih besar dari 0,05 dan $\mathrm{t}_{\text {hitung }} 2,772>\mathrm{t}_{\text {tabel }} 1,997$. Persamaan regresi linear sederhana $\mathrm{Y}=13,329+0,664\left(\mathrm{X}_{2}\right)$. Koefisien determinasi menunjukkan Stres Kerja $\left(\mathrm{X}_{1}\right)$ memberikan kontribusi terhadap kinerja $(\mathrm{Y})$ sebesar $39,7 \%$ sedangkan sisanya $60,3 \%$ di luar penelitian ini.

Motivasi dan stres kerja secara serempak berpengaruh signifikan terhadap kinerja karyawan CV Muslim Galeri Indonesia. Hal ini dapat dilihat dari nilai sig lebih kecil dari taraf kesalahan 0,05 $(0,000>0,05)$ dan nilai $\mathrm{F}_{\text {hitung }}>\mathrm{F}_{\text {tabel }}$ yaitu $36,777>$ 3,140 . Untuk kontribusi variabel bebas terhadap terikat didapat nilai Adjusted $R$ Square sebesar 0,520 . Ini artinya $52,0 \%$ perubahan kinerja dapat dijelaskan oleh variabel motivasi dan stres kerja, Sisanya 48,0 \% dipengaruhi oleh variabel lain di luar penelitian ini.

Berdasarkan perhitungan koefisien korelasi (R) menunjukkan bahwa hubungan antara variabel motivasi dan stres kerja memiliki hubungan yang erat terhadap kinerja karyawan CV Muslim Galeri Indonesia. Dengan nilai koefisian korelasi 0,731 yang masuk pada kriteria KUAT (0,60-0,799).

\section{PENGHARGAAN}

Ucapan terima kasih sampaikan kepada seluruh pihak yang telah membantu penyelesaian penelitian ini. Terutama untuk CV Muslim Galeri Indonesia.

\section{DAFTAR PUSTAKA}

Algifari. (2010). Analisis Regresi Teori, Kasus dan Solusi Edisi Kedua. Yogyakarta: BPFE.
Andre M.C Mamesah, L. K. (2016). Lingkungan Kerja Secara Parsial Secara Berpengaruh Signifikan Terhadap Kinerja Karyawan.

Arif.Ramadhani. (2011). Penilaian Kinerja. Jakarta: PT.Sarana Panca Karya Nusa.

Djastuti, N. P. (2015). Disiplin kerja budaya organisasi dan lingkungan kenerja secara simultan dan parsial berpengaruh secara signifikan terhadap kinerja pegawai.

Gozali, I. (2012). Aplikasi analisis Multivariate Dengan Program IMB SPSS. Semarang: Universitas Diponegoro.

Handoko, T. H. (2008). Manajemen Personalia dan Sumber Daya Manusia. Yogyakarta: Liberty.

Hasibuan, M. (2012). Manajemen Sumer Daya Manusia. Jakarta: PT Bumi Askara.

Istijanto. (2005). Aplikasi Praktis Riset Pemasaran. Jakarta: Pt,Garmadia Pustaka Utama.

M.Baiquni, W. d. (2011). Perencanaan dan Pengembangan Pariwisata. Bandung: Lubuk Agung.

Mangkunegara, A. P. (2008). Perencanaan Pengembangan Sumber Daya Manusia. Bandung: REFLIKA ADITAMA.

Nasution. (2009). Metode Research (Penelitian Ilmiah). Jakarta: Bumi Aksara Permendiknas No. 22 Tahun 2006 Tentang Standar isi.

Nawawi, H. (2006). Evaluasi dan Manajemen Kinerja di Lingkungan. Yogyakarta: Gadjah Mada Univercity Press.

Ramadhani, A. (2012). Penilaian Kinerja. PT. Sarana Panca Karya Nusa.

Rivai, V. (2003). Manajemen Sumber Daya Manusia untuk Perusahaan. Jakarta: Rajagrafindo Persada.

Sri, W. (2016). Manajemen Sumber Daya Manusia; Teori Perencanan Stretegi, Isu-Isu Utama dan Globalisasi. Bandung: Minggu Media.

Sugiyono. (2015). Metode Penelitian Manajemen. Bandung: CV Alfabeta.

Taufiq, Z. H. (2012). Secara Parsial Lingkungan Kerja Mempunyai Pengaruh Terhadap Kinerja Karyawan.

Tuti, I. D. (2015). Disiplin Kerja Secara Parsial Berpengaruh Secara Signifikan Terhadap Kinerja Pegawai.

Wardianto dan M, B. (2011). Perencanaan dan Pengembangan Pariwisata. Bandung: Lubuk Agung. 